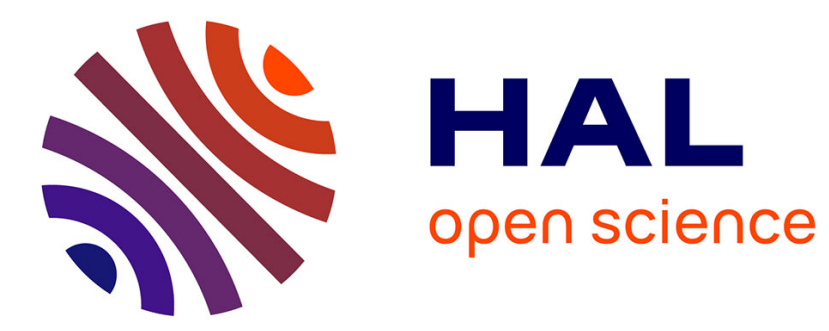

\title{
Survival of faecal indicator bacteria in treated pig manure stored in clay-covered heaps in Vietnam
}

Son Thi Thanh Dang, Dung van Truong, Henry Madsen, Anders Dalsgaard

\section{To cite this version:}

Son Thi Thanh Dang, Dung van Truong, Henry Madsen, Anders Dalsgaard. Survival of faecal indicator bacteria in treated pig manure stored in clay-covered heaps in Vietnam. Veterinary Microbiology, 2011, 152 (3-4), pp.374. 10.1016/j.vetmic.2011.05.004 . hal-00724206

\section{HAL Id: hal-00724206 \\ https://hal.science/hal-00724206}

Submitted on 20 Aug 2012

HAL is a multi-disciplinary open access archive for the deposit and dissemination of scientific research documents, whether they are published or not. The documents may come from teaching and research institutions in France or abroad, or from public or private research centers.
L'archive ouverte pluridisciplinaire HAL, est destinée au dépôt et à la diffusion de documents scientifiques de niveau recherche, publiés ou non, émanant des établissements d'enseignement et de recherche français ou étrangers, des laboratoires publics ou privés. 


\section{Accepted Manuscript}

Title: Survival of faecal indicator bacteria in treated pig manure stored in clay-covered heaps in Vietnam

Authors: Son Thi Thanh Dang, Dung Van Truong, Henry Madsen, Anders Dalsgaard

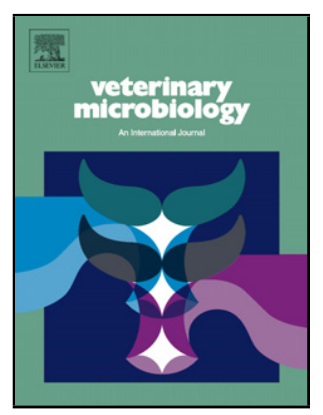

PII:

S0378-1135(11)00268-9

DOI: doi:10.1016/j.vetmic.2011.05.004

Reference: VETMIC 5301

To appear in: $\quad$ VETMIC

Received date: $\quad 26-11-2010$

Revised date: $\quad 3-5-2011$

Accepted date: $\quad 4-5-2011$

Please cite this article as: Dang, S.T.T., Van Truong, D., Madsen, H., Dalsgaard, A., Survival of faecal indicator bacteria in treated pig manure stored in clay-covered heaps in Vietnam, Veterinary Microbiology (2010), doi:10.1016/j.vetmic.2011.05.004

This is a PDF file of an unedited manuscript that has been accepted for publication. As a service to our customers we are providing this early version of the manuscript. The manuscript will undergo copyediting, typesetting, and review of the resulting proof before it is published in its final form. Please note that during the production process errors may be discovered which could affect the content, and all legal disclaimers that apply to the journal pertain. 
1 Survival of faecal indicator bacteria in treated pig manure stored in clay-covered

\section{2 heaps in Vietnam}

3

4

5 Son Thi Thanh Dang ${ }^{\mathrm{a}, \mathrm{b}}$, Dung Van Truong ${ }^{\mathrm{a}}$, Henry Madsen ${ }^{\mathrm{b}}$, and Anders Dalsgaard ${ }^{\mathrm{b}}$ 6

$7 \quad{ }^{a}$ National Institute of Veterinary Research, No.86 Truong Chinh street, Dong Da, Ha

8 Noi, Viet Nam; ${ }^{b}$ Department of Veterinary Disease Biology, Faculty of Life Sciences,

9 University of Copenhagen, Groennegaardsvej 15, DK-1870 Frederiksberg C, Denmark.

10

11 Email addresses: Son Thi Thanh Dang: chienson2006@ yahoo.com; Dung Van Truong:

12 qunglam@yahoo.com; Henry Madsen: hmad@life.ku.dk; Anders Dalsgaard:

13 ad@life.ku.dk.

14

15

16

17

18

$19 *$ Corresponding author: Faculty of Life Sciences, University of Copenhagen,

20 Groennegaardsvej 15, DK-1870 Frederiksberg C, Denmark. phone: +45 35332720; fax:

$21+4535332755$.

22 


\section{Abstract}

Small-scale pig farmers in Vietnam typically store manure in heaps covered by a

30 layer of clay. However, the hygienic quality of manure applied to agricultural soil is

31 uncertain as storage time is determined by the need for soil fertilizer. This study aimed

32 to assess how the storage of pig manure added straw, lime stone or urea in heaps covered by clay affected the survival of faecal bacteria. $E$. coli was reduced from $4 \log _{10}$

$34 \mathrm{CFU} / \mathrm{g}$ to below the detection limit within two weeks with $2 \%$ w/w urea $\left(\mathrm{CO}\left(\mathrm{NH}_{2}\right)_{2}\right)$

35 whereas other amendments were associated with limited E. coli reductions.

36 Enterococcus spp. were not reduced in any heaps indicating possible re-growth and that

37 enterococci should be used as hygiene indicators with caution. Follow-up research

38 should document the practical conditions under which the farmer practice of storing

39 manure with a clay cover can be utilized to obtain a bactericidal effect of ammonia and

40 a safe product with high fertilizer value.

41

42 Key words: Pig manure, urea, ammonia, E. coli, survival, Vietnam. 


\section{Introduction}

The pig population in Viet Nam is expected to reach more than 33 million by 2011 (Huynh et al. 2007) with small-scale pig farming accounting for about $80 \%$ of pig production (Lapar et al. 2003). Current management practices of pig manure in Vietnam as well as other developing countries, i.e. collection, storage, transportation, treatment and application, show that pig manure is mainly used as fertilizer in agricultural fields (e.g. rice, maize) and gardens (root and leafy vegetables) or is discharged into aquatic recipients, including fish ponds (Guan and Holley 2003;Unc and Goss 2004; Vu et al. 2007). Little knowledge is available about environmental hygiene and veterinary public health hazards of such practices, e.g. occupational risks and food safety, including type and transmission of main pathogens.

Vietnamese farmers typically add rice straw, plant waste, ash or lime stone to manure to absorb liquid and to make it easier to handle and process, i.e. in small manure heaps typically covered with a layer of clay that prevents dogs and other animals to access and destroy the heaps (Vu, Tran, \& Dang 2007). Composting and storage periods vary between 3-4 months depending on crop growth periods and needs for fertilizer, but with little if any awareness of hygiene impacts.

The use of a layer of clay on manure heaps implies reduced aeration, which is likely to reduce the temperature development in the manure because the aerobic and heat-generating composting process is inhibited. As temperature and exposure time are key factors determining pathogen survival (Guan and Holley 2003;Nicholson et al. 2005), the hygienic safety of manure treated by current management practices is uncertain. On the other hand, the combined use of clay cover and addition of lime stone and possible urea may increase $\mathrm{pH}$ and ammonia concentrations to levels that could significantly inactivate pathogens so the manure can safely be disposed off or used as fertilizer (Vinnerås, 2007). The objective of this study was to assess how the storage of pig manure added straw, lime stone, or urea in heaps covered by clay as practiced by 
71 Vietnamese farmers affect hygienic quality as determined by the survival of the faecal

72 indicator bacteria E. coli and Enterococcus spp..

73

\section{2. Materials and methods}

75

76

77

\subsection{Treatment and storage of pig manure}

The study was conducted from January to March, 2008, at a small-scale farm located in peri-urban Hanoi. This period is the coldest in northern Vietnam with night temperatures down to $8-15^{\circ} \mathrm{C}$. Survival of faecal bacterial indicators and pathogens are usually longer at such low temperatures compared to the higher temperatures found during the rest of year. Three heaps were made by mixing $500 \mathrm{~kg}$ of fresh solid pig manure with $50 \mathrm{~kg}$ rice straw only, $50 \mathrm{~kg}$ rice straw $+2 \%$ lime stone $\left(\mathrm{CaCO}_{3}\right)$, or $50 \mathrm{~kg}$ rice straw $+2 \% \mathrm{w} / \mathrm{w}$ urea $\left(\mathrm{CO}\left(\mathrm{NH}_{2}\right)_{2}\right)$, respectively; and the heaps were then covered by a $3-\mathrm{cm}$ thick mud layer (Table 1 ). The addition of rice straw or other organic straw material as well as lime stone is a normal practice of Vietnamese farmers. Lime stone is traditionally added to the manure when making the heap partly to absorb liquid (i.e. urine and water) but mainly because farmers use lime stone as fertilizer in the rice field (Vu et al. 2007). Vietnamese farmers do not have any tradition of using slaked lime and the associated increased $\mathrm{pH}$ levels as a sanitizer of organic wastes. The urea was added to test effect on survival of faecal bacterial indicators at elevated ammonia levels, which is produced when urea hydrolyses in the manure. All material in each heap was mixed well with a shovel before covered by mud. Six glass thermometers were placed in six different locations inside each heap to measure possible differences in development of temperature. Those locations involved dividing each of the composting heaps into three vertical parts (top, center, and bottom). Samples and temperature measurements were collected at the right and left inside of the heap for all three parts of the heap. The bottom radius of the heaps was about $2 \mathrm{~m}$ and they had a height of about $1.3 \mathrm{~m}$. 


\subsection{Sample collection and enumeration of fecal bacterial indicators}

Samples were collected at days 0, 14, 28 and 45 during storage of the manure. At these four sampling times, sub-samples (100 g/sample) were collected from each of the six locations in the heap. The samples were collected by carefully digging a sterile hard plastic tube into the different locations in the heap. The mud crust was initially removed from the area in which the plastic tube was to be inserted. Immediately after collecting the sample, mud crust was placed to cover the hole made thereby minimizing the entry of air into the heap. Also, it was noted that the hole made during sampling most often quickly disappeared due to replacement of heap material. The samples were transported to the laboratory in an insulated box with cooling elements and then analyzed the same day for numbers of E. coli and Enterococcus spp. as well as total coliforms. A 10-g subsample was weighed and added $90 \mathrm{ml}$ peptone (Oxoid, Cambridge, England) diluents containing $0.9 \% \mathrm{NaCl}$ to make a stock solution $\left(10^{-1}\right)$. This solution was serially diluted from $10^{-1}$ to $10^{-8}$, and $100 \mu \mathrm{l}$ samples were subsequently taken from each dilution and spread on Selective E. coli/coliform Chromogenic medium agar plates (Oxoid) and Slanetz \& Batley agar plates (Oxoid) for enterococci enumeration. Each dilution was analyzed in duplicate and agar plates were incubated at $44{ }^{\circ} \mathrm{C}$ for $24 \mathrm{~h}$ before bacterial colonies were enumerated. The number of CFU (cell forming units)/g stored manure of each indicator bacteria were calculated based on enumerations in two sequential dilutions.

\section{3. $\mathrm{pH}$ and moisture content measurements}

The $\mathrm{pH}$ of manure samples was determined by $\mathrm{pH}$ meter (Precisa model $\mathrm{pH} 900$,

Zürich, Switzerland) one hr after the samples were mixed with distilled water (1:5 v: v). Samples were stored in sterile glass vials with closed lids. The moist manure samples were weighed and dried in an oven at $100-105^{\circ} \mathrm{C}$ for $6-8 \mathrm{hrs}$. The weight of the initial 
124 moist sample was subtracted the remaining dry weight and the moisture content was

125 then expressed as a percentage of the wet weight.

126

127

\subsection{Statistical analysis}

128 Bacterial counts were logarithmically transformed (base 10) after adding 1 and these were then analyzed using multiple linear regressions with location of manure sample in

130 the heap, method of treatment and storage time as categorical variables. Model assumptions, normality and homogeneity of variance, were assessed by plots of residuals, i.e. histogram and residual versus fitted plots, respectively. Temperature, moisture content and $\mathrm{pH}$ were also added as explanatory factors in the model. This was done one at a time due to the small sample size. P-values of $<0.05$ were considered significant.

\section{Results and discussions}

\subsection{Bacterial elimination in manure heap added straw and urea}

The addition of $2 \%$ urea to the manure was associated with a fast and significant reduction in numbers of E. coli and total coliforms (Figs. 1 and 2). None of the bacterial counts varied significantly among locations within the heap on day 0 . The $\mathrm{pH}$ was

142 slightly alkaline (mean value of 8.5$)$ and increased over time $(\mathrm{p}<0.001)$. It was higher in

143 the middle and bottom section of the heap than in the top layer $(\mathrm{p}<0.01)$. No apparent

144 temperature increase was seen with a maximum measured temperature of $33{ }^{\circ} \mathrm{C}$ (Table

145 1). At day 0 , the mean $\log _{10}$ value concentrations of $E$. coli and total coliforms were

1464.22 and $5.11(\mathrm{CFU} / \mathrm{g})$, respectively. Two weeks later numbers of E. coli and total

147 coliforms were below the detection limit of $<5(\mathrm{CFU} / \mathrm{g})$ manure. At day 45 , total

148 coliforms were found at low concentration $0.72 \log _{10} \mathrm{CFU} / \mathrm{g}$ which is likely due to re-

149 growth of some of the non-faecal bacterial species represented in the group of total coliform bacteria, e.g. Citrobacter spp. or Arizona spp.. 
The fast reduction of $E$. coli and Gram-negative rods in the presence of ammonia

152 in animal manure is supported by earlier studies where Salmonella was eliminated

153 within two weeks at $14{ }^{\circ} \mathrm{C}$ in cow manure added $2 \%$ w/w urea (Ottoson et al. 2008).

154 The concentration of Enterococcus spp. in this treatment did not vary

significantly by location within the heap and varied during the experiment $(\mathrm{p}<0.05)$ with

an initial concentration of $3.97 \log _{10} \mathrm{CFU} / \mathrm{g}$ at day 0 and a similar concentration at day

45, i.e $3.62 \log _{10} \mathrm{CFU} / \mathrm{g}$ (Fig. 3). The genus Enterococcus consists of several species of

which some, e.g. E. faecium and E. faecalis, are strictly of faecal origin. However, some

species, e.g. E. casseliflavus and E. mundtii, are not of faecal origin and may be found

in the environment, e.g. as plant-associated species (Petersen and Dalsgaard 2003). It is

unknown to what extent the added rice straw may have contributed with such non-faecal

162 Enterococcus spp. as initial analyses of rice straw for enterococci were not done. The

163 apparent lack of reduction in numbers of enterococci may be explained by survival and

multiplication of non-fecal Enterococcus spp., despite a reduction of Enterococcus spp.

of strictly faecal origin. Preliminary studies of Enterococcus spp. survival in stored

human urine did show elimination of E. faecium and E. faecalis, but clonal re-growth of

167 E. gallinarum (unpublished data). Our findings are supported by (Ottoson, Nordin, von

168 Rosen, \& Vinnerås 2008) that also found only limited reductions in numbers of enterococci in cow manure containing $2 \% \mathrm{w} / \mathrm{w}$ urea stored at $14{ }^{\circ} \mathrm{C}$. Here it was suggested that Gram-positive cocci with their lower cell-permeability as well as surfaceto-volume ration are less susceptible to ammonia than Gram-negative rods. Further studies should investigate possible re-growth of certain Enterococcus spp. by determination of species and genotypes involved as well as the explanatory factors associated with a possible reduced susceptibility of Enterococcus spp. to ammonia. In conclusion, E. coli seems to be a more appropriate bacterial indicator as compared with 
179 The addition of straw only significantly reduced numbers of E. coli only (Fig. 1).

180 Counts of $E$. coli differed between these two treatments $(\mathrm{p}<0.05)$ and varied over time

181 ( $\mathrm{p}<0.001)$, while there was no effect of location. The interaction between the two

182 treatments and time was not significant (location was dropped from this model).

183 Concentration of E. coli in the heap added straw only was reduced from $4.20 \log _{10}$

$184 \mathrm{CFU} / \mathrm{g}$ on day 0 to $1.63 \log _{10} \mathrm{CFU} / \mathrm{g}$ after 45 -days of storage. The mean temperature in

185 this manure heap was $34{ }^{\circ} \mathrm{C}$ with a maximum temperature of $47{ }^{\circ} \mathrm{C}$ registered at days 2 ,

1863 and 4 and $\mathrm{pH}$ was neutral (7.5) with little changes measured (Table 1). These findings

187 indicate that E. coli and therefore possible also other Gram-negative rods, e.g.

188 Salmonella, are reduced significantly (2-log units) in clay-covered heaps with pig

189 manure amended rice straw following six weeks of storage. However, it should be noted

190 that a similar reduction in E. coli numbers was not seen in manure heaps added straw

191 together with lime (Fig. 1). It is difficult to explain this apparent lack of E. coli

192 reduction in the heap with lime, but it may partly be explained by little if any

193 temperature development in this heap (mean temperature of $29^{\circ} \mathrm{C}$ ). It should also be

194 noted that the addition of lime stone had limited effect on $\mathrm{pH}$ which was only slightly

195 alkaline $(\mathrm{pH}=8.4)$

196 Numbers of total coliforms were not reduced during storage of manure added

197 straw only and lime stone/straw with CFU/g ranging from 5-6 $\log _{10}$ (Fig. 2).

198 Interestingly, however, total coliform counts were significantly higher at the bottom of

199 the heaps than in the top and the middle part $(\mathrm{p}<0.001)$. Enterococcus spp. counts did

200 not differ significantly among locations in the heaps but differed between the two

201 treatments $(\mathrm{p}<0.05)$ and varied among time points $(\mathrm{p}<0.001)$. Enterococcus spp. counts

202 were higher in the treatment with lime than in the treatment with only straw at days 15 ,

20330 and 45. An increase in CFU/g was seen at day 15 ( $\mathrm{p}<0.001)$ followed by a decline

204 until day 45 (Fig. 3). 


\subsection{Influence of temperature, $\mathrm{pH}$, and moisture content}

207 Temperature varied significantly over time $(\mathrm{p}<0.001)$ and differed between the three

208 different manure heaps $(\mathrm{p}<0.001)$ after adjusting for variation over time and location in

209 the heaps. Temperature did not vary significantly among the three locations within the

210 heaps. Also $\mathrm{pH}$ varied over time $(\mathrm{p}<0.001)$ and between the three types of manure heaps

$211(\mathrm{p}<0.001)$ and variation among locations within heaps was not significant. Moisture

212 content only varied significantly over time, i.e. a gradual decline $(\mathrm{p}<0.001)$. $\mathrm{pH}$ was

213 negatively associated $(\mathrm{p}<0.01)$ with total coliforms counts after adjusting for main

214 effects of the composition of the heap (straw only versus straw/lime) and time.

215 Similarly, $\mathrm{pH}$ was negatively associated with enterococci counts $(\mathrm{p}<0.05)$ after

216 adjusting for main effects of all three compositions of manure heaps and sampling

217 times.

The practice of almost all small-scale Vietnamese pig farmers in Northern

219 Vietnam is to cover manure heaps with clay. The readily availability of urea at low cost

220 offers a unique opportunity to utilize ammonia to inactivate pathogens and produce a

221 hygienic safe fertilizer with reduced storage time allowing the farmers to apply the

222 manure when needed in the field. Ammonia $\left(\mathrm{NH}_{3}\right)$ is a small, uncharged molecule that

223 can cross the membrane of bacteria and damage the cell either by causing rapid

224 alkalinization of the cytoplasm or through a decrease in intracellular $\mathrm{K}+$ concentration

225 (Kadam and Boone 1996;Park and Diez- Gonzalez 2003). A negative effect on Gram-

226 negative bacteria has been reported at ammonia concentrations $>30 \mathrm{mM}$ (Park and

227 Diez- Gonzalez 2003). A higher $\mathrm{pH}$ will result in higher concentrations of uncharged

228 ammonia. Thus, a higher pathogen die-off from urea treatment can be achieved by a

229 combined effect of ammonia and carbonate by the addition $\mathrm{Na}_{2} \mathrm{CO}_{3}$ or lime stone

$230\left(\mathrm{CaCO}_{3}\right)$ at $\mathrm{pH}$ 9.5. However, it should be noted that in the current experiments, mean

$231 \mathrm{pH}$ values were only 8.4 and 8.5 in manure heaps added rice straw/lime stone and rice 
straw/urea, respectively (Table 1). Since ammonia concentrations were not measured in

233 the heaps, we do not know if the reported ammonia threshold value of $30 \mathrm{mM}$ ammonia

234 needed to produce a hygienic safe fertilizer were obtained. In addition to reducing

235 bacterial faecal indicators and pathogens, ammonia is also known to cause similar

236 reductions of viruses and helminth parasites (Nordin et al. 2009; Vinnerås et al. 2008).

237 Further studies, including cost-benefit analyses, should be done to evaluate whether the

238 mixing of different concentrations of urea with pig manure are applicable to common

239 operational practices of rural Vietnamese farmers as well as meeting the soil

240 requirements for nitrogen. In particular, it is of interest to determine the level of

241 ammonia gas emission in manure heaps covered by clay as is the normal practice of

242 Vietnamese farmers. It could be that the clay cover together with the practice to apply

243 manure by hand reduces ammonia emission to acceptable low levels at which the

244 fertilizer value of the added nitrogen is maintained. Further, the addition of urea may

245 enable the farmers to obtain a more rapid hygienization of the stored manure that will

246 allow them to apply safe manure fertilizers when nutrients are demanded by crops.

\section{4. Conclusion}

249 Further studies should determine under which conditions the common practice of

250 Vietnamese farmers to cover their manure heaps with clay can be utilized to obtain a

251 safe and high-value fertilizer by adding urea and utilize the bactericidal effect of the

252 ammonia generated. Documentation should be generated on the percentage of urea,

253 amount of straw material, $\mathrm{pH}$ and other conditions needed to obtain ammonia

254 concentrations sufficient to inactivate both bacterial, viral and parasite pathogens.

255 Considerations should be given to cost-effectiveness and applicability to common

256 operational practices of rural Vietnamese farmers. 
This study was a part of $\mathrm{PhD}$ project, funded by the Danish International Development

Assistance (Danida) (SUSANE- research project No. J.nr.104. Dan.8.L.722). We thank

261

262

263

264

Tien Minh Tran for collaboration in pilot studies and guidance in establishing the

manure heaps and conducting the analyses of physico-chemical parameters. Sang

Nguyen Anh provided excellent support managing the manure heaps and during sample collection. Ms. Huong from the Hanoi Agricultural University is thanked for help with the bacterial enumerations. Lars Stoumann Jensen is thanked for critical comments to the manuscript.

\section{References}

Guan, T.Y. \& Holley, R.A. 2003. Pathogen survival in swine manure environments and transmission of human enteric illness: A review. J.Environ.Qual., 32, 383-392

Huynh, T.T.T., Aarnink, A.J.A., Drucker, A., \& Verstegen, M.W.A. 2007. Pig Production in Cambodia, Laos, Philippines, and Vietnam: A Review. Asian J.Agric.Dev., 4, 70-90

Kadam, P.C. \& Boone, D.R. 1996. Influence of $\mathrm{pH}$ on ammonia accumulation and toxicity in halophilic, methylotrophic methanogens. Appl.Environ.Microbiol., 62, 44864492

Lapar, M.L., Vu, T.B., \& Ehui, S. 2003. Identyfying barriers to entry to livestock input and output markets in Southeast Asia: The case of Vietnam. Socioecon.Policy Res., 56, $1-50$

Nicholson, F.A., Groves, S.J., \& Chambers, B.J. 2005. Pathogen survival during livestock manure storage and following land application. Bioresour.Technol., 96, 135143

Nordin, A., Nyberg, K., \& and Vinnerås, B. 2009. Inactivation of Ascaris eggs in source-separated urine and feces by ammonia at ambient temperatures.

Appl.Environ.Microbiol., 75, 662-667

Ottoson, J., Nordin, A., von Rosen, D., \& Vinnerås, B. 2008. Salmonella reduction in manure by the addition of urea and ammonia. Bioresour.Technol., 99, 1610-1615

Park, G.W. \& Diez- Gonzalez, F. 2003. Utilization of carbonate and ammonia-based treatments to eliminate Escherichia coli O157:H7 and Salmonella Typhimurium DT104 from cattle manure. J.Appl.Microbiol., 94, 675-685

Petersen, A. \& Dalsgaard, A. 2003. Species composition and antimicrobial resistance genes of Enterococcus spp, isolated from integrated and traditional fish farms in Thailand. Environ.Microbiol., 5, 395-402 
296 Unc, A. \& Goss, M.J. 2004. Transport of bacteria from manure and protection of water

297 resources. Appl.Soil Ecol., 25, 1-18

298 Vinnerås, B., Nordin, A., Niwagaba, C., \& Nyberg, K. 2008. Inactivation of bacteria

299 and viruses in human urine depending on temperature and dilution rate. Water Res., 42,

$300 \quad 4067-4074$

301 Vu, T.K.V., Tran, M.T., \& Dang, T.T.S. 2007. A survey of manure management on pig

302 farms in Northern Vietnam. Livest.Sci., 112, 288-297

303

304

305 
306 Table 1: Characteristics and composition of heaps with pig manure.

307

308 Figure 1. Temporal reduction of E. coli in heaps with stored pig manure following

309 different treatment methods.

310

311 Figure. 2. Temporal reduction of total coliforms in stored pig manure.

312

313 Figure. 3. Temporal reduction of Enterococcus spp. in stored pig manure. 
Table 1: Characteristics and composition of heaps with pig manure.

\begin{tabular}{|c|c|c|c|}
\hline $\begin{array}{l}\text { Characteristics/ } \\
\text { Composition of } \\
\text { manure heap }\end{array}$ & $\begin{array}{l}500 \mathrm{~kg} \text { manure, } \\
50 \mathrm{~kg} \text { rice straw }\end{array}$ & $\begin{array}{l}500 \mathrm{~kg} \text { manure, } 50 \mathrm{~kg} \\
\text { rice straw, } 2 \% \text { lime stone } \\
\left(\mathrm{CaCO}_{3}\right)\end{array}$ & $\begin{array}{l}500 \mathrm{~kg} \text { manure, } 50 \mathrm{~kg} \\
\text { rice straw, } 2 \% \mathrm{w} / \mathrm{w} \\
\text { urea }\end{array}$ \\
\hline $\begin{array}{l}\text { Duration of storage } \\
\text { (days) }\end{array}$ & 45 & 45 & \\
\hline Moisture (\%) & $67.9 \pm 4.6$ & $67.6 \pm 3.8$ & $67.7 \pm 5.7$ \\
\hline $\mathrm{pH}$ & $7.5 \pm 1.2$ & $8.4 \pm 0.6$ & $8.5 \pm 0.3$ \\
\hline Temperature $\left({ }^{\circ} \mathrm{C}\right)$ & $34.3 \pm 7.7$ & $23.9 \pm$ & $26.4 \pm 2.5$ \\
\hline $\begin{array}{l}\text { Maximum } \\
\text { temperature }\left({ }^{\circ} \mathrm{C}\right)\end{array}$ & 47 & 29 & 33 \\
\hline $\begin{array}{l}\text { Time with highest } \\
\text { measured } \\
\text { temperature }\end{array}$ & Days 2, 3, 4 & Days $10-18$ & Days $6,7,8$ \\
\hline
\end{tabular}




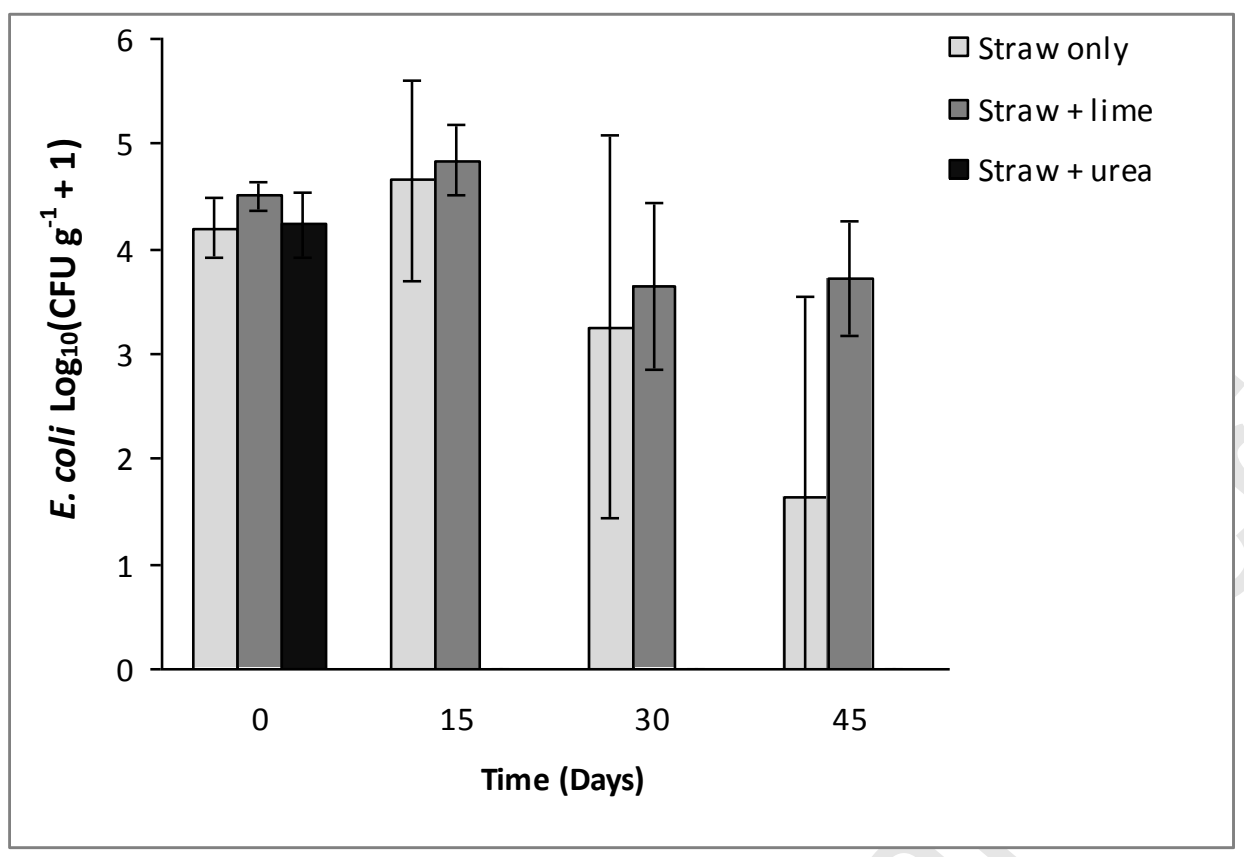




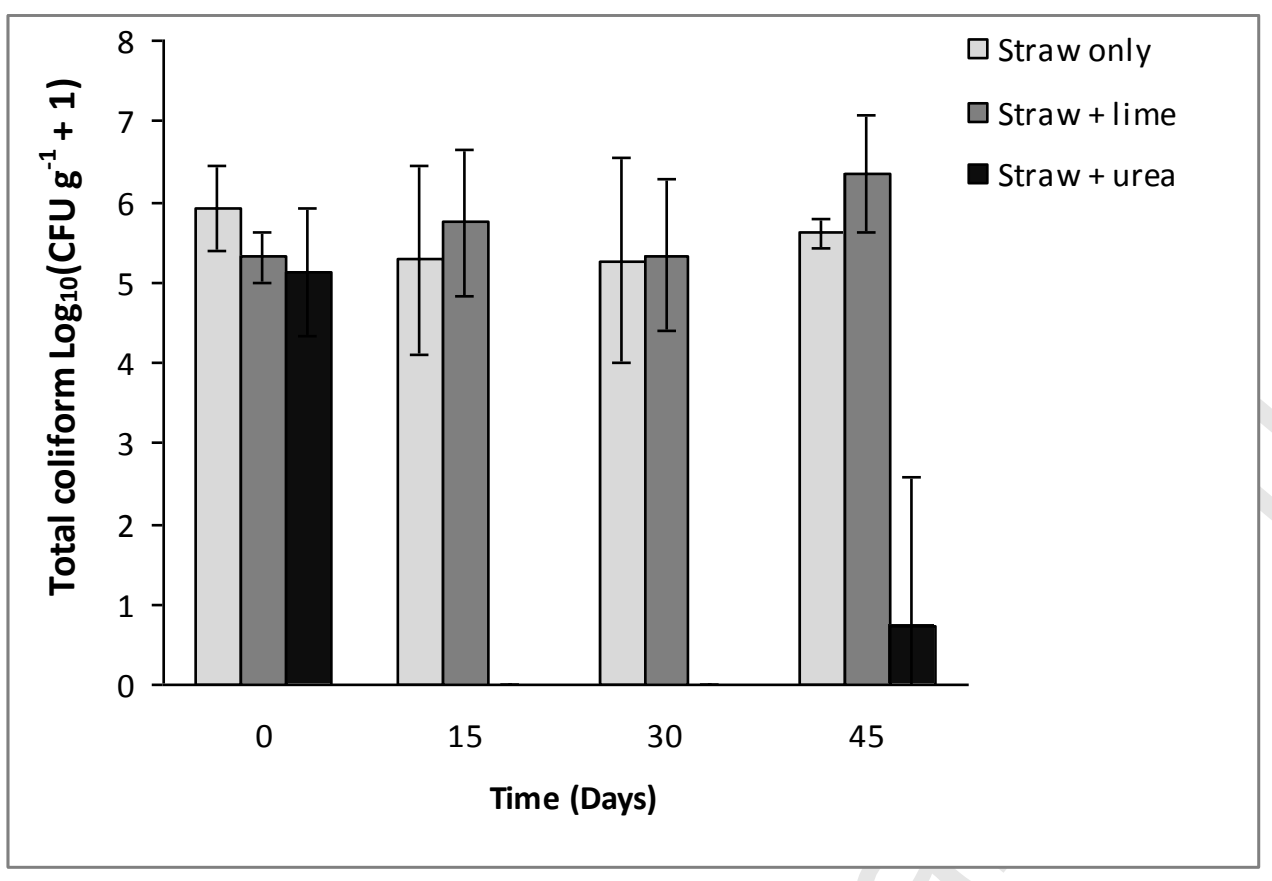




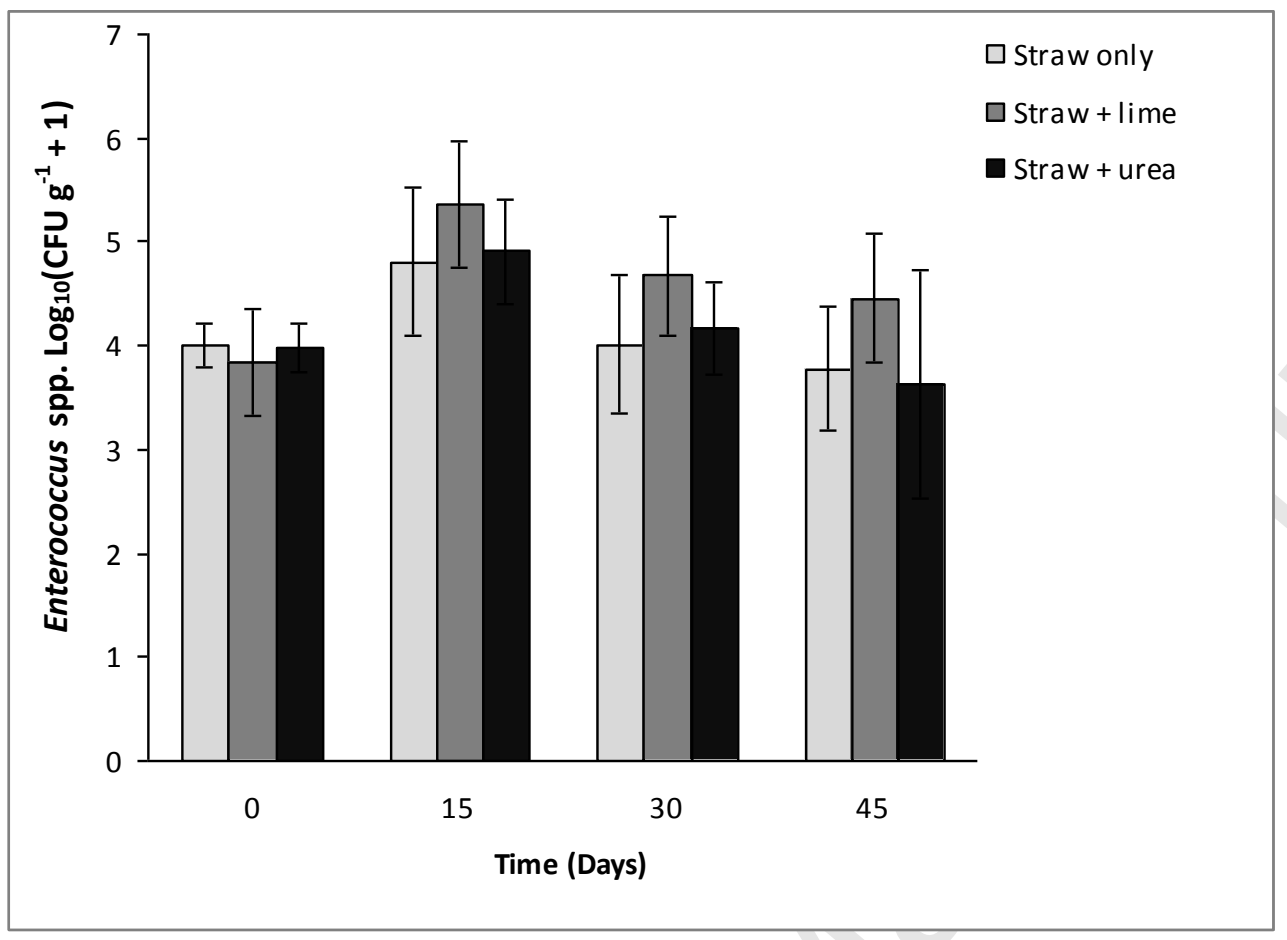

